\title{
A bántalmazás és a koraszülés összefüggései a kétéves kori pszichomotoros fejlődés tükrében
}

\author{
Szele Anna Szabina egészségpszichológus-hallgató ${ }^{1}$ - Nagy Beáta Erika dr. ${ }^{2}$ \\ Debreceni Egyetem, 'Népegészségügyi Kar, Magatartástudományi Intézet, \\ ${ }^{2}$ Általános Orvostudományi Kar, Gyermekgyógyászati Intézet, Debrecen
}

\begin{abstract}
Bevezetés: Hazánkban a koraszülések magas száma miatt népegészségügyileg kiemelten fontos feladatunk a koraszülött gyermekek vizsgálata és a fejlődésükre ártalmas tényező́k azonosítása.

Célkitüzés: A koraszülött gyermekek pszichomotoros fejlődésének felmérése, az édesanya által átélt bántalmazás és a gyermek pszichomotoros teljesítménye közötti összefüggés megvizsgálása.

Módszer: Extrém kis (<1000 g) és igen kis (1000-1500 g) születési súlyú koraszülött, a vizsgálat idején 23-30 hónap közötti gyermek $(\mathrm{n}=35)$ pszichomotoros teljesítményének (Brunet-Lézine; Bayley-III) és az anya által átélt bántalmazásnak a felmérése (saját kérdőív).

Eredmények: Elemzéseink alapján megállapítható, hogy az alacsonyabb születési súly alacsonyabb pszichomotoros mutatókkal és magasabb fejlódési rizikóval társul. Az anya által átélt gyermekkori bántalmazás szoros összefüggést mutat a koraszülött gyermekek teljesítményeivel.

Következtetések: A szerzők szeretnék felhívni a figyelmet a koraszülött gyermekek szúróvizsgálatának fontosságára, továbbá a gyermekkori bántalmazásnak és következményeinek súlyosságára. A korai fejlesztés szükségességének felismerésével nemcsak megelőzhetővé, hanem redukálhatóvá is válna a későbbi zavarok, viselkedésproblémák megjelenése.

Orv Hetil. 2017; 158(25): 976-983.
\end{abstract}

Kulcsszavak: koraszülés, alacsony születési súly, pszichomotoros fejlódés, bántalmazás

\section{The connection between maltreatment and preterm birth - in the light of psychomotor development at 2 years old}

\begin{abstract}
Introduction: Preterm children' development and harmful affecting factors to development are important aspects of public health, because in our country the number of preterm birth is very high.

Aim: Description of psychomotor development of preterm children (Brunet-Lézine; Bayley-III) and connection between psychomotor development and maternal abuse history (own questionnaire).

Method: Extremely $(<1000 \mathrm{~g})$ and very low $(1000-1500 \mathrm{~g})$ birth weight preterm children at 23-30 months $(\mathrm{n}=35)$ and their mothers' abuse history were measured.

Results: Lower birth weight was associated with lower psychomotor development quotients and higher development risk. Strong associations were found between maternal history of childhood abuse and the development quotients. Conclusions: We would like to draw attention to the importance of assessing preterm children, as well as to the importance of maltreatment and the severity of its consequences. With the early recognition of necessity for developmental interventions we can prevent problems in the future.
\end{abstract}

Keywords: preterm birth, low birth weight, psychomotor development, maltreatment

Szele ASz, Nagy BE. [The connection between maltreatment and preterm birth - in the light of psychomotor development at 2 years old]. Orv Hetil. 2017; 158(25): 976-983.

(Beérkezett: 2017. március 30.; elfogadva: 2017. április 29.) 


\section{Rövidítések}

$\mathrm{BQ}$ = beszédkészség-hányados; $\mathrm{FQ}$ = fejlődési hányados; $\mathrm{KQ}$ = szenzomotoros koordinációs hányados; $\mathrm{PQ}=$ poszturális adaptációs hányados; $S Z Q$ = szociabilitáshányados

Az emberi fejlődés korai időszakának feltérképezése és segítése az elmúlt évtizedek során világszerte a figyelem középpontjába került [1]. Népegészségügyileg fontos feladatunk az egyes rizikócsoportok fejlődésének feltérképezése. Veszélyeztetett (high-risk/at risk child) populációnak azon gyermekek csoportjait nevezhetjük, akiknél a későbbi életkorokban az átlagosnál nagyobb eséllyel figyelhető meg intellektuális, érzelmi vagy szociális deficit, így például a koraszülött és alacsony születési súlyú gyermekeknél [2]. A koraszülöttség egyaránt veszélyeztetô tényező lehet az eltérô fejlődésre, tanulási, illetve viselkedési problémák megjelenésére [3]. Mindemellett az újszülöttkori (neonatalis) halálozás egyik vezető és második leggyakoribb oka az ötéves kor előtt bekövetkező halálozásoknak - ebból adódóan egy adott nemzet egészségügyi mutatójának is tekinthetó [4].

Hazánkban a koraszülés szinte népbetegségnek tekinthetô jelenség [5]. Az újszülöttek döntő többsége több mint 90\%-a - normális testtömeggel születik, és a későbbi életévek során is problémamentesen fejlődik. Azonban cseppet sem elhanyagolható számadat, hogy 8\% körül van azon gyermekek aránya, akik korán - a 37. gesztációs hét előtt - jönnek a világra [6]. A Központi Statisztikai Hivatal tájékoztatási adatbázisát 2005-2015 között áttekintve, megállapítható, hogy hazánkban a koraszülések száma emelkedő tendenciát mutat (1. táblá$z a t)$.

Kutatásunk során az Egészségügyi Világszervezet (WHO) definíciójára támaszkodtunk, amely alapján $k o-$ raszülöttnek azokat az élő újszülötteket tekinthetjük, akiknek gesztációs ideje nem haladja meg a 37 hetet, vagyis a 259 napot [7]. Ennek alsó határa 1997 óta, a

1. táblázat | A koraszülések száma és százalékos arányai hazánkban 20052015 között (Forrás: http://statinfo.ksh.hu/)

\begin{tabular}{lccc}
\hline & $\begin{array}{c}\text { Élveszületések } \\
\text { száma (fó) }\end{array}$ & $\begin{array}{c}\text { Koraszülések } \\
\text { száma (fö) }\end{array}$ & $\begin{array}{c}\text { Százalékos arány } \\
(\%)\end{array}$ \\
\hline 2005 & 97496 & 8206 & 8,4 \\
2006 & 99871 & 8363 & 8,3 \\
2007 & 97613 & 8424 & 8,6 \\
2008 & 99149 & 8881 & 8,9 \\
2009 & 96442 & 8399 & 8,7 \\
2010 & 90335 & 8039 & 8,8 \\
2011 & 88049 & 7691 & 8,7 \\
2012 & 90269 & 7996 & 8,8 \\
2013 & 88689 & 7989 & 9,0 \\
2014 & 91510 & 8090 & 8,8 \\
2015 & 91690 & 7993 & 8,7 \\
\hline
\end{tabular}

CLIV. Egészségügyi törvény alapján a betöltött 24. terhességi héttel kezdődik [8]. Továbbá figyelembe vettük a koraszülöttséggel gyakran együtt járó és átfedő perinatalis rizikót, az alacsony születési súlyt [7]. Egy érett újszülött átlagos születési súlya 3000-3500 gramm, születési hossza pedig 48-52 cm között mozog [3]. Ennek függvényében a nemzetközi adatokat megvizsgálva hazánk igencsak kedvezőtlen adatokkal rendelkezik. Az Európai Unió tagországainak 2012. évi alacsony születési súly gyakorisági eredményei alapján Magyarország a negatív rangsor harmadik helyén helyezkedik el $(8,6 \%)$ Ciprust (11,5\%) és Görögországot $(9,8 \%)$ követve [9].

Vizsgálatunkban a WHO születési súly szerinti osztályozását alapul véve, kis születési súlyúnak a 2500 grammnál kisebb gyermekeket tekinthetjük. E kategórián belül további két csoportot különíthetünk el $[7,8]$ :

- kis születési súly (<2500 gramm)

- igen kis születési súly (1000-1500 gramm),

- extrém/igen-igen kis születési súly (<1000 gramm).

Vizsgálatunk egy nagyobb kutatás pilot tanulmányát képezi. A vizsgált alacsony születési súlyú és koraszülött gyermekekkel kapcsolatos eredmények egy részlete kerül bemutatásra.

\section{Bántalmazás mint a koraszülésre hajlamosító tényező}

A koraszülésnek számos potenciális oka lehet, amelyek közül máig vannak feltáratlan területek a tudományban [8]. A szakirodalmat áttekintve megállapítható, hogy hazánkban a gyermekkori bántalmazás, a párkapcsolati erőszak és a koraszülés közötti összefüggések vizsgálata még egy teljesen új területnek tekinthető. A külföldi szakirodalom azonban jelentős eredményeket ismertet a témában, a probléma relevanciájára felhívva ezzel a figyelmet [10-13]. Kutatásunk során egy általunk kidolgozott kérdôív segítségével megvizsgáltuk a bántalmazás és a koraszülés, illetve a gyermek fejlődési mutatói közötti kapcsolatot.

A korai ártalmak komoly hatást gyakorolhatnak az egyén fejlődésére. A gyermekkori bántalmazás mint interperszonális traumatizáció definiálható [14]. A WHO meghatározása alapján a gyermekbántalmazás négy formáját különíthetjük el: fizikai, szexuális, érzelmi (pszichológiai) bántalmazást és elhanyagolást [15]. A gyermekkorban történt bántalmazás és a koraszülés közötti kapcsolat evidenciája nem teljesen egyértelmú, s máig tisztázatlan, hogy milyen típusú, súlyosságú, hosszúságú bántalmazás hozható összefüggésbe a koraszüléssel. Az összefüggés feltárására azonban egyre több a kezdeményezés, s olyan kutatási eredmények vannak, amelyek nem hagyhatók figyelmen kívül $[10,11]$.

A legtöbb tanulmány a gyermekkori szexuális bántalmazás és a koraszülés közötti kapcsolatot tárgyalja [11]. Egy 2010-es vizsgálatban a bántalmazás ezen formáját átélt nők körében nemcsak a koraszülés aránya volt magasabb, de gyakrabban kerültek kórházba a terhesség 
alatt, s több komplikációval is szembesültek [12]. Wosu és mtsai [10] epidemiológiai áttekintése 1992 és 2010 között hat publikált tanulmányt vizsgált meg a témában. Három tanulmányt szürtek ki, amelyekben pozitív szignifikáns kapcsolat volt a koraszülés és a gyermekkori szexuális bántalmazás között. Selk és mtsai [11] a közel 52000 fónyi mintanagyságú kutatásukban megállapították, hogy a gyermekkorukban szexuális bántalmazás áldozataivá vált nők körében $22 \%$-kal magasabb volt a koraszülés aránya.

A partnerbántalmazásnak - a nemek közötti egyenlőtlenségen alapuló, nők elleni erőszak egyik formájának öt fajtáját különíthetjük el: szóbeli, lelki, testi, szexuális és gazdasági-társadalmi eröszak, amelyeket rendszerint a (volt) házastárs, (volt) élettárs vagy a (volt) partner követ el [16]. A WHO a nők elleni erőszak egészségügyi következményei és hatásai között a nem kívánt terhességek létrejötte mellett a vetélés, halvaszületés, koraszülés és a kis súllyal született gyermekek világrahozatalának nagyobb fokú kockázatára hívja fel a figyelmet. Szerintük a nők elleni erőszak a járványokkal egyenértékű közegészségügyi probléma. A családon belüli erôszakról hazánkban 1999-ben készült először reprezentatív felmérés. A következőt 2014-ben az Európai Unió Alapjogi Ügynöksége készítette a nők elleni erőszak megjelenő fajtáiról. Mindkét felmérés arra az eredményre vezetett, hogy Magyarországon minden negyedik nő élete során legalább egy olyan párkapcsolatba kerül, amelyben a partner bántalmazza [17]. 2012-es adatok alapján hazánkban jelenleg körülbelül kétmillió nő él, akit lelkileg súlyosan bántalmaz a partnere, s 261000 él olyan párkapcsolatban, amelyben testi és/vagy szexuális erőszak áldozatává válik [16].

Hill és mtsai [13] metaanalízise, 19 átfogó tanulmányt megvizsgálva, a partnerbántalmazás és a koraszülés, alacsony születési súly, intrauterin fejlődési retardáció közötti kapcsolat jellegzetességeit kísérelte meg feltárni. A koraszülés és alacsony születési súly pozitív kapcsolatot mutatott a partnerbántalmazással, míg az intrauterin fejlődési retardáció esetében nem volt levonható ilyen konzekvencia.

\section{A koraszülött gyermekek fejlődési jellegzetességei}

A koraszülött gyermekek idegrendszere éretlen állapotban kényszerül a külső környezeti tényezők közé [18]. Számos fejlődésneurológiai következmény azonosítható - előfordulhat apnoe, légúti infekciók, infantilis respirációs distressz szindróma (IRDS), bronchopulmonalis dysplasia (BPD), hallászavar, di- vagy tetraplegia. Szintén gyakori a retinopathia (ROP), amelyre annál fogékonyabbak az újszülöttek, minél éretlenebbek [19]. Az idő előtti születés azonban akkor is rizikótényezőt jelent a későbbi problémákat (például: viselkedészavar, tanulási és koordinációs problémák) tekintve, ha a gyermeknél nem volt tapasztalható maradandó sérülés [20].
Az alacsonyabb születési súly és gesztációs kor szignifikánsan magasabb kognitív és nyelvi károsodásokkal, illetve viselkedésproblémákkal jár együtt. Bhutta és mtsai [21] metaanalízise kimutatta, hogy a koraszülött gyermekek iskolás korukban szignifikánsan nagyobb mértékben mutatnak kognitív deficitet, figyelmi és viselkedésproblémát, mint a kilenc hónapra született társaik. A nyelvi fejlődés késése - így receptív és expresszív téren is - szintén magasabb [22]. Továbbá ezen gyermekek nagyobb mértékben mutatnak viselkedési és pszichiátriai problémákat - szorongás, depresszió, agresszió, ambivalens viselkedés, figyelmi nehézségek előfordulása valószínúbb [23].

Egy 2014-es vizsgálatban 2,5 éves korú extrém mértékű koraszülött gyermekek pszichomotoros teljesítményét kilenc hónapra született gyermekekkel összehasonlítva azt tapasztalták, hogy mind kognitív, nyelvi és motoros szinten is szignifikánsan alacsonyabb mutatókkal jellemezhetők a koraszülött gyermekek [24]. Sansavini és mtsai [25] szintén hasonló eredményeket tapasztaltak. Feltételezték, hogy a motoros problémák negatívan befolyásolják a kommunikációs készségeket, így például a szemtől szembe interakciót, a közös figyelmet, valamint a nyelvelsajátítást.

Ionio és mtsai [26] szegényebb nyelvi és kognitív készségekről, Benassi és mtsai [27] pedig szegényebb gesztusfejlődésről, motoros készségekről számoltak be koraszülött gyermekek esetében. Sok esetben a kognitív és nyelvi készségek deficitje együtt jár, de előfordul, amikor a nyelvi késés kognitív lemaradás nélkül jelentkezik [28]. Összességében elmondható, hogy mind metaanalíziseket, mind pedig a friss 2011-2016 közötti szakirodalmat áttekintve a koraszülött gyermekek szignifikánsan alacsonyabb kognitív, nyelvi (receptív és expresszív), illetve motoros (finommozgás és nagymozgás) teljesítményt érnek el, mint a kilenc hónapra született gyermekek. Leginkább nyelvi és motoros téren tapasztalható nagyobb fokú lemaradás.

\section{Módszer}

Kutatásunk kivitelezését az Egészségügyi Tudományos Tanács Tudományos és Kutatásetikai Bizottsága hagyta jóvá (54037-5/2016/EKU).

\section{Kérdésfelvetés, hipotézisek}

Kutatásunk fó célja a bántalmazás, koraszülés, születési súly és a fejlődési mutatók közötti összefüggések megvizsgálása volt. Kutatásunk során annak megválaszolására törekedtünk, hogy tapasztalható-e jelentős különbség a koraszülött gyermekek vizsgált csoportjai pszichomotoros teljesítményében, illetve az anya által átélt bántalmazás befolyásolja-e a vizsgált gyermekek fejlődési színvonalát. Kérdéseink megválaszolásának elősegítése érdekében az alábbi hipotéziseket alkottuk: 
1. hipotézis: Az extrém kis születési súlyú (<1000 g) gyermekek gyengébb teljesítményt érnek el a nyelvi és motoros skálákon, mint az igen kis születési súlyú (1000$1500 \mathrm{~g})$ gyermekek $[25,29]$.

2. hipotézis: A gyermekkorban, illetve a partnerkapcsolatban bántalmazást átélt anyák gyermekei alacsonyabb gesztációs héttel, születési súllyal és fejlődési mutatókkal jellemezhetőek [30].

\section{A vizsgálati minta}

Vizsgálati mintánk 35, a Debreceni Egyetem Klinikai Központjának Neonatológiai Szakrendelésére, illetve Gyermekgyógyászati Intézetébe, extrém kis (<1000 g) és igen kis (1000-1500 g) születési súlyú, koraszülött utógondozói státuszvizsgálatra visszahívott, 23-30 hónap közötti gyermekből állt, akik mindegyike a Debreceni Egyetem Klinikai Központjának Szülészeti és Nögyógyászati Klinikáján született 2014-ben. Mivel ez a populáció fokozott biológiai sérülékenységgel jön a világra, s a későbbiek során is veszélyeztetettebb az eltérő fejlődésmenetre, orvosi és fejlődési vizsgálatra történő visszahívásuk kiemelten fontos. A gyermekek a Neonatológiai Szakrendelo" adatbázisából születési idő és súly alapján lettek kiválasztva. Vizsgálati időpontra történő behívásuk postai és telefonos úton történt. Az extrém kis születési súlyúak csoportjában 17, míg az igen kis születési súlyúak csoportjában 18 gyermeket vizsgáltunk.

\section{Vizsgálati eszközök}

1. A pszichomotoros fejlődés felmérésére hazánkban 1980 óta az egyik leggyakrabban alkalmazott, adaptált és standardizált vizsgálati eljárást, a francia Brunet-Lézine fejlődési tesztet alkalmaztuk [31]. Az eszköz próbákból és a szülő által megválaszolandó kérdésekből áll. A próbák 0-30 hónapos korig nyújtanak információt a pszichomotoros fejlődés négy részterületéről: mozgás/poszturális adaptáció (P); szenzomotorikus koordináció/ manipuláció (K); beszéd (B) és szociabilitás (SZ). A skála pontozási rendszere által nemcsak egy globális fejlődési kvócienst (FQ), hanem az egyes részterületek fejlődési kvócienseit (PQ, KQ, BQ, SZQ) is kiszámíthatjuk. Ebból adódóan könnyen megállapítható, hogy a fejlődés melyik területén tapasztalható elmaradás. A globális fejlődési kvóciens (FQ) fiatalkorban az IQ-t helyettesítő mutató, amely akkor tekinthető abnormálisnak, ha 70nél alacsonyabb értéket vesz fel [32].

2. Hazánkban a 2016-ban adaptált és jelenleg standardizálás alatt álló, korunk legkorszerúbb, a fejlődést legkomplexebb módon feltérképező pszichodiagnosztikai eszközével, a Bayley-III-mal (Bayley Csecsemó és Kisgyermek Skálák, Harmadik kiadás) is lehetöségünk adódott a pszichomotoros teljesítmény felmérésére. A teszt elsődleges célja a megkésett fejlődésû gyermekek beazonosítása, az esetleges beavatkozások, terápiák megtervezésének elősegítése, valamint a többnyire későbbi életkorokban tapasztalható viselkedési, figyelmi és tanulási zavarok szürése. Segítségével specifikusabb, részletesebb és pontosabb képet kaphatunk a gyermek fejlődési mutatóit illetően. A csecsemő- és kisgyermekkori fejlődést öt fó területen vizsgálja - kognitín, nyelvi, motoros, társas-érzelmi és adaptív viselkedéses szinten - 1-42 hónapos kor között. Továbbá a nyelvi skálán belül megkülönböztet receptín és expresszin kommunikációt, a motoros skálán belül pedig finommozgás és nagymozgás szubteszteket [33].

3. Ahhoz, hogy a Brunet-Lézine- és a Bayley-III vizsgálóeljárásokkal nyert eredményeket kontextusba tudjuk helyezni, s a koraszülést, a gyermek fejlődését esetlegesen befolyásoló tényezőket ki tudjuk szúrni, elengedhetetlen volt egy kérdóívcsomag kidolgozása, amelyben többek között információt kértünk arra vonatkozóan, hogy az édesanyát 18 éves kora előtt érte-e fizikai, szexuális, érzelmi bántalmazás, elhanyagolás (például „Előfordult-e Önnel, hogy fizikailag bántalmazták, például megütötték, pofon vágták?”), illetve terhessége során partnere részéről tapasztalt-e szóbeli, lelki, testi, szexuális és/vagy gazdasági-társadalmi erőszakot (például „Elöfordult-e a terhesség alatt, hogy például partnere korlátozta mozgásszabadságát, cselekvési szabadságát, kritizálta, megkérdo"jelezte döntéseit vagy megalázta mások elótt, az Ön számára kedves tárgyakat rongálta, állatokat bántalmazta?”). Kérdőívünket a nemzetközi traumakérdőívekre (például Adverse Childhood Experience Questionnaire) és szakirodalomra támaszkodva dolgoztuk ki. Kérdéseinket igyekeztünk tapintatosan megfogalmazni, s példákkal szemléltetni. Egy ötpontos skálán értékeltettük az előfordulási gyakoriságukat (ahol 1 = párszor életemben, 5 = naponta).

\section{A vizsgálat menete}

A vizsgálatok a pszichodiagnosztikai elveknek megfelelően kerültek felvételre a Gyermekgyógyászati Intézet pszichológiai szakrendelőjében. A tesztfelvételi környezet kialakítása során ügyeltünk rá, hogy a szoba barátságos, csendes és világos, illetve mentes legyen minden olyan ingertől, ami elterelhetné a gyermek figyelmét. A gyermekkel történő pszichológiai fejlődésvizsgálat általában 90-100 percet vett igénybe, amely idő alatt a gondozó kitöltötte az általunk használt kérdőíveket. A pszichológiai vizsgálatot minden esetben egy orvosi státuszvizsgálat követte, többek között a testsúly, magasság, fejkörfogat felmérése.

\section{Az adatok statisztikai feldolgozása}

A vizsgálat statisztikai részét az SPSS 2.0.0.0 statisztikai program segítségével készítettük el. Az adatok feldolgozásának megkezdése előtt egymintás Kolmogorov-Szmirnov-normalitásvizsgálatot végeztünk, amely alapján megállapítottuk, hogy a legtöbb változó nem követ normáleloszlást, így a továbbiakban nemparaméteres eljárá- 
sokkal dolgoztunk. Az adatokból készítettünk egy korrelációs mátrixot, majd a Spearman-féle rangkorrelációs eljárás segítségével kiszámoltuk az egyes változók közötti korrelációs értékeket. A csoportonkénti összehasonlításokra Mann-Whitney-próbákat használtunk.

\section{Eredmények}

\section{Általános adatok (átlagok és szórások)}

A vizsgálati mintánkban megvizsgált 35 gyermek születési súlya 470 és 1490 gramm között mozgott. Az 1000-1500 gramm között született gyermekek születési súlya szinte duplája volt $(M=1348,3 ; S D=129,17)$ az 1000 gramm alatti gyermekek születési súlyához képest $(\mathrm{M}=715,3 ; \mathrm{SD}=175,14)$. A betöltött terhességi hét az igen kis születési súlyú gyermekeknél átlagosan 31 hét $(\mathrm{M}=30,94 ; \mathrm{SD}=2,04)$, míg az extrém kis súlyú gyermeknél jóval alacsonyabb $(M=26,70 ; S D=2,64)$ volt ez az érték. A vizsgálatok elvégzésekor a gyermekek valódi életkoruk szerint átlagosan 26,3 hónapos korúak voltak $(M=790,3$ nap; $S D=46,85)$.

\section{Születési súly és pszichomotoros teljesitmény}

Mivel a Brunet-Lézine pszichomotoros fejlődési teszt esetében rendelkezünk magyar standarddal, a skálaeredményeket össze tudtuk vetni az ajánlott átlagos normaértékkel. Mintánk 91,4\%-a átlagos teljesítményű volt, vagyis fejlődési kvóciense (FQ) 70 feletti értéket vett fel, 8,6\%-uk azonban életkorához képest megkésett fejlődésünek bizonyult. A részképességeket megvizsgálva elmondható, hogy súlycsoporttól függetlenül a minta 5,7\%-a a poszturális adaptáció, vagyis a nagymozgás (például járás, lépcsőzés), 8,5\%-a a szociabilitás (például szobatisztaság, társas alkalmazkodás), 11,6\%-a a szenzomotorikus koordináció, avagy a finommozgás (például tárgyakkal való manipuláció), 17,1\%-a pedig az expreszszív-receptív beszéd területén mutatkozott megkésett fejlődésűnek. Kutatásunk során kontrollcsoport bevonására már nem volt alkalmunk, így az Odett Brunet és Irene Lézine által meghatározott referenciaértéket használhatjuk (FQ = 100), amely a gyermek életkorának megfelelő teljesítményt mutatja. Ez az érték az igen kis születési súlycsoportban $(\mathrm{FQ}=91)$ nem áll olyan távol a referenciaértéktől, azonban az extrém kis születési súlycsoportban $(\mathrm{FQ}=84)$ jelentősen alulmarad - tehát magasabb pszichomotoros rizikóval jellemezhetőek.

Feltételeztük, hogy az extrém kis születési súlyú $(<1000 \mathrm{~g})$ gyermekek gyengébb teljesítményt érnek el a nyelvi és motoros skálákon, mint az igen kis születési súlyú (1000-1500 g) gyermekek [25, 32]. A mediánokat megvizsgálva megállapítható, hogy az extrém kis születési súlyú gyermekek minden skálaváltozó esetén alacsonyabb eredményt értek el, mint az igen kis születési súlyú gyermekek - így a nyelvi és motoros skálákon is, mind a Brunet-Lézine, mind pedig a Bayley-III vonatko- zásában (2. és 3. táblázat). A Bayley-III skálái esetén nem tapasztaltunk szignifikáns különbséget a születési súly függvényében, egyedül az önszabályozást, a világ iránti érdeklődést, az érzelmek interaktív használatának képességét mérô társas-érzelmi skálán mutatkozott tendenciaszerü különbség ( $\mathrm{U}=211 ; \mathrm{p}=0,057)$. A Brunet-Lézine fejlődési teszt esetén a fejlödési kvóciens $(\mathrm{U}=216,5 ; \mathrm{p}=$ $0,035)$, a beszéd $(\mathrm{U}=220,5 ; \mathrm{p}=0,025)$, illetve a szociális helyzetekhez való adaptálódást vizsgáló szociabilitás $(\mathrm{U}=222 ; \mathrm{p}=0,022)$ kvóciens esetén mutatkozott szignifikáns differencia a két csoport között.

\section{Bántalmazás és pszichomotoros teljesitmény}

Mintánkban a partnerbántalmazás nem, míg a gyermekkori bántalmazás három típusa - szexuális $(\mathrm{n}=2)$, fizikai $(\mathrm{n}=8)$ és érzelmi $(\mathrm{n}=17)$ - fordult elő. Feltételeztük, hogy a gyermekkori bántalmazást átélt anyák gyermekei alacsonyabb gesztációs héttel, születési súllyal és fejlődési mutatókkal jellemezhetőek [30].

A gesztációs héttel és a születési súllyal egyik bántalmazást mérő változónk sem korrelált, azonban a fejlődési mutatók vonatkozásában jelentős összefüggéseket tapasztaltunk. A fizikai bántalmazás gyakoriságát mérő változó és a Bayley-III, illetve a Brunet-Lézine egyes skálái között szignifikáns negatív korreláció állapítható meg

2. táblázat $\mid$ Az extrém kis és az igen kis születési súlyú gyermekek BrunetLézine-eredményei (medián, p-érték)

\begin{tabular}{llll}
\hline & $\begin{array}{l}\text { Extrém kis } \\
\text { súly }(\mathrm{n}=17)\end{array}$ & $\begin{array}{l}\text { Igen kis súly } \\
(\mathrm{n}=18)\end{array}$ & Szignifikancia \\
\hline $\begin{array}{l}\text { Fejlődési kvóciens } \\
(\text { FQ) }\end{array}$ & 84 & 91 & $\mathrm{p}=0,035^{*}$ \\
$\begin{array}{l}\text { Poszturális adaptáció } \\
(\text { PQ) }\end{array}$ & 90 & 94,5 & $\mathrm{p}=0,134$ \\
$\begin{array}{l}\text { Szenzomotorikus } \\
\text { koordináció (KQ) }\end{array}$ & 84 & 88,5 & $\mathrm{p}=0,072$ \\
$\begin{array}{l}\text { Beszéd (BQ) } \\
\text { Szociabilitás (SZQ) }\end{array}$ & 84 & 90,5 & $\mathrm{p}=0,025^{*}$ \\
\hline
\end{tabular}

*Független mintás Mann-Whitney-próba, p<0,05

3. táblázat $\mid$ Az extrém kis és az igen kis születési súlyú gyermekek BayleyIII-eredményei (medián, p-érték)

\begin{tabular}{llll}
\hline & $\begin{array}{l}\text { Extrém kis súly } \\
(\mathrm{n}=17)\end{array}$ & $\begin{array}{l}\text { Igen kis súly } \\
(\mathrm{n}=18)\end{array}$ & Szignifikancia \\
\hline Kognitív skála & 95 & 100 & $\mathrm{p}=0,258$ \\
Nyelvi skála & 86 & 91 & $\mathrm{p}=0,126$ \\
Motoros skála & 85 & 88 & $\mathrm{p}=0,546$ \\
Társas-érzelmi skála & 90 & 100 & $\mathrm{p}=0,057$ \\
$\begin{array}{l}\text { Adaptív viselkedés } \\
\text { skála }\end{array}$ & 78 & 100 & $\mathrm{p}=0,103$ \\
\hline
\end{tabular}

*Független mintás Mann-Whitney-próba, p<0,05 
A fizikai bántalmazás és a fejlődési tesztek egyes változói közötti szignifikáns korrelációk

\begin{tabular}{lc}
\hline & $\begin{array}{c}\text { Fizikai bántalmazás } \\
(\mathrm{n}=8)\end{array}$ \\
\hline Bayley-III - Nyelvi skála & $-0,387^{*}$ \\
Bayley-III - Expresszív nyelvi szubteszt & $-0,434^{*}$ \\
Bayley-III - Motoros skála & $-0,370^{*}$ \\
Bayley-III - Finommozgás szubteszt & $-0,382^{*}$ \\
Brunet-Lézine - FQ & $-0,439^{*}$ \\
Brunet-Lézine - SZQ & $-0,369^{*}$ \\
Brunet-Lézine - BQ & $-0,376^{*}$ \\
\hline
\end{tabular}

Spearman-féle rangkorreláció, ${ }^{*} \mathrm{p}<0,05$

5. táblázat | A fizikailag bántalmazott és nem bántalmazott anyák gyermekeinek fejlődési teljesítménye a Bayley-III skáláin (medián, szélsó értékek, p-érték)

\begin{tabular}{lll|ll|l}
\hline & $\begin{array}{l}\text { Bántal- } \\
\text { mazott } \\
(\mathrm{n}=8)\end{array}$ & $\begin{array}{l}\text { Szélsón } \\
\text { értékek }\end{array}$ & $\begin{array}{l}\text { Nem } \\
\text { bántal- } \\
\text { mazott } \\
(\mathrm{n}=27)\end{array}$ & $\begin{array}{l}\text { Szélsó } \\
\text { értékek }\end{array}$ & Szignifikancia \\
\hline $\begin{array}{l}\text { Kognitív } \\
\text { skála }\end{array}$ & 90 & $60-110$ & 100 & $65-125$ & $\mathrm{p}=0,117$ \\
$\begin{array}{l}\text { Nyelvi } \\
\text { skála }\end{array}$ & 82,5 & $65-97$ & 91 & $59-118$ & $\mathrm{p}=0,028^{*}$ \\
$\begin{array}{l}\text { Motoros } \\
\text { skála }\end{array}$ & 79 & $52-110$ & 91 & $73-110$ & $\mathrm{p}=0,036^{*}$ \\
$\begin{array}{l}\text { Társas- } \\
\text { érzelmi } \\
\text { skála }\end{array}$ & 92,5 & $65-105$ & 95 & $80-140$ & $\mathrm{p}=0,310$ \\
$\begin{array}{l}\text { Adaptív } \\
\text { viselkedés } \\
\text { skála }\end{array}$ & 75 & $18-113$ & 101 & $26-164$ & $\mathrm{p}=0,055$ \\
\hline
\end{tabular}

*Független mintás Mann-Whitney-próba, p<0,05

6. táblázat

A fizikailag bántalmazott és nem bántalmazott anyák gyermeke inek fejlődési teljesítménye a Brunet-Lézine skáláin (medián, szélső értékek, p-érték)

\begin{tabular}{|c|c|c|c|c|c|}
\hline & $\begin{array}{l}\text { Bántal- } \\
\text { mazott } \\
(\mathrm{n}=8)\end{array}$ & $\begin{array}{l}\text { Szélső } \\
\text { értékek }\end{array}$ & $\begin{array}{l}\text { Nem } \\
\text { bántal- } \\
\text { mazott } \\
(\mathrm{n}=27)\end{array}$ & $\begin{array}{l}\text { Szélső } \\
\text { értékek }\end{array}$ & Szignifikancia \\
\hline $\begin{array}{l}\text { Fejlődési } \\
\text { kvóciens (FQ) }\end{array}$ & 82 & $53-95$ & 91 & $62-103$ & $\mathrm{p}=0,012^{*}$ \\
\hline $\begin{array}{l}\text { Poszturális } \\
\text { adaptáció } \\
(\mathrm{PQ})\end{array}$ & 82,5 & $43-99$ & 92 & $73-108$ & $\mathrm{p}=0,055$ \\
\hline $\begin{array}{l}\text { Szenzo- } \\
\text { motorikus } \\
\text { koordináció } \\
\text { (KQ) }\end{array}$ & 88 & $52-88$ & 90 & $62-108$ & $\mathrm{p}=0,036^{*}$ \\
\hline Beszéd (BQ) & 79,5 & $55-92$ & 90 & $45-104$ & $\mathrm{p}=0,032^{*}$ \\
\hline $\begin{array}{l}\text { Szociabilitás } \\
\text { (SZQ) }\end{array}$ & 87,5 & $44-99$ & 92 & $62-108$ & $\mathrm{p}=0,236$ \\
\hline
\end{tabular}

*Független mintás Mann-Whitney-próba, $\mathrm{p}<0,05$
(4. táblázat). Ez azt jelenti, hogy minél gyakoribb volt a fizikai bántalmazás az anya életében, gyermeke fejlődési mutatói annál alacsonyabbak voltak.

Összehasonlításra kerültek a gyermekkorukban bántalmazott és nem bántalmazott nők gyermekeinek fejlődési tesztekben nyújtott teljesítményei. A fizikai bántalmazás vonatkozásában a mediánok szintjén minden skálaváltozó esetén megfigyelhető, hogy a bántalmazott anyák gyermekei alacsonyabb teljesítményt értek el (5. és 6. táblázat). Ez a különbség szignifikánsnak bizonyult a Bayley-III nyelvi $(\mathrm{U}=152 ; \mathrm{p}=0,028)$ és motoros $(\mathrm{U}=149,5 ; \mathrm{p}=0,036)$ skáláinál, illetve az expresszín nyelvi $(\mathrm{U}=158 ; \mathrm{p}=0,013)$ és finommozgás $(\mathrm{U}=15 \mathrm{l}$; $\mathrm{p}=0,032)$ szubtesztjeinél.

A Brunet-Lézine $F Q(\mathrm{U}=159 ; \mathrm{p}=0,012)$, a finom mozgást mérő szenzomotorikus koordináció $(\mathrm{U}=149,5$; $\mathrm{p}=0,036)$ és beszéd $(\mathrm{U}=150,5 ; \mathrm{p}=0,032)$ változói esetén mutatkozott szignifikáns különbség.

$\mathrm{Az}$ érzelmi bántalmazás vonatkozásában egyedül a Bayley-III finommozgást és nagymozgást méró motoros skáláján találtunk szignifikáns $(\mathrm{U}=191 ; \mathrm{p}=0,049)$ különbséget a bántalmazott és nem bántalmazott anyák gyermekei között - az érzelmileg bántalmazott nók gyermekei motoros teljesítménye lényegesen alacsonyabb volt.

\section{Megbeszélés}

\section{A születési súly és a pszichomotoros teljesitmény összefüggései}

Általánosan elfogadott, hogy nagyobb fokú biológiai sérülékenységük miatt az extrém kis $(<1000 \mathrm{~g})$ születési súlyú gyermekek alacsonyabb fejlódési mutatókkal jellemezhetőek, mint az igen kis (1000-1500 g) születési súlyúak [29]. Ezt támasztotta alá egy friss, a koraszülöttek minden súlycsoportját felölelő hazai kutatás is. Az alacsonyabb születési súly a neuromotoros fejlődés vonatkozásában fokozott kockázattal társult [34]. A nemzetközi szakirodalomban továbbá közismert, hogy a koraszülött gyermekek föleg nyelvi és motoros készségek területén mutatnak elmaradást [25]. Mintánkban a szakirodalommal összecsengő eredményeket tapasztaltunk. Az extrém kis születési súlyú gyermekek mindkét pszichomotoros teszt skálaváltozóin alacsonyabb értékeket értek el. A legjelentősebb különbség a Brunet-Lézineteszt globális fejlődési teljesítményt mérő $F Q$ változója, valamint az expresszív, vagyis kifejező és a receptív, vagyis értő nyelvi készségeket mérô nyelvi, illetve szociális készségek területén mutatkozott.

\section{A gyermekkori bántalmazás kapcsolata a pszichomotoros teljesitménnyel}

Mintánkban az anyák több mint fele (54,2\%-a) tapasztalta a bántalmazás valamilyen formáját 18 éves kora előtt. 
Két anya esetében a gyermekkori bántalmazás fizikai, szexuális és érzelmi formái együttesen fordultak elő, négy anya esetében pedig a fizikai és érzelmi bántalmazás együttes jelenléte volt megfigyelhető. Partnerbántalmazásra utaló eredményeket nem tapasztaltunk - ennek hátterében az állhatott, hogy a vizsgálatra az édesanyák sok esetben az édesapákkal együtt érkeztek, ebból kifolyólag pedig elképzelhető, hogy az érintettségről kevésbé mertek nyilatkozni.

A szakirodalomból ismert, hogy a gyermekkorukban bántalmazott anyák alacsonyabb mentális egészségi mutatókkal jellemezhetőek, amelyek érzéketlen és inkonzisztens szülői bánásmóddal [30], illetve bizonytalan kötődési stílussal [35] is társulhatnak. Mintánkban, feltételezésünkkel összhangban, a gyermekkorukban fizikailag bántalmazott anyák gyermekei pszichomotoros fejődési mutatói alacsonyabbnak bizonyultak, mint a nem bántalmazottaké - leginkább a nyelvi és motoros készségeket tekintve. Míg az érzelmi bántalmazás vonatkozásában a motoros fejlődés alacsonyabb értékét találtuk. Eredményeinket szakirodalmi kontextusba helyezve feltételezhetőnek tartjuk, hogy a gyermekkorukban bántalmazott anyák esetleges kiszámíthatatlan és bizonytalanabb szülői viselkedése miatt gyermekeik fejlődése akadályoztatottabb pályát követ - kevésbé dinamikus -, ebből kifolyólag készségelsajátításuk nehézkesebb, fejlődésmutatókkal jellemezhető teljesítményük pedig alacsonyabb.

\section{Következtetések}

Évente csaknem több mint 8000 gyermek születik hazánkban a 37. terhességi hét előtt. Éretlenségükből adódóan fokozott biológiai kockázatnak vannak kitéve. A későbbi fejlődés során gyakoribb náluk a viselkedési, figyelmi és koncentrációs, valamint a részképességzavarok megjelenése. Mint veszélyeztetett populáció, rendkívül fontos a szekunder prevenció szempontjából a pszichomotorosfejlődés-vizsgálat megvalósítása - rendszeresen, de legalább kétéves korban. Ezáltal időben kiszürhetővé válnak a fejlődésben mutatkozó lemaradások, és amenynyiben szükséges, elkezdhetjük tervezni az intervenció harmadlagos szintjét, a rehabilitációt, a korai fejlesztést. $\mathrm{Az}$ intervenciók szükségességének felismerésével megelőzhetővé válna a későbbi problémák, zavarok megjelenése.

Vizsgálatunk korlátai között szerepel az alacsony mintaelemszám, a kontrollcsoport hiánya és a vizsgálati körülmények kontrollálásának gyengesége (például édesapák jelenléte a kérdőív kitöltése alatt). A jövőben, ezeket kiküszöbölve, szeretnénk minél nagyobb mintán folytatni a koraszülött-populáció szürését, kibővítve más egyéb rizikócsoport és átlagos, időre született gyermekek vizsgálatával. A gyermekkorban átélt fizikai bántalmazás és a pszichomotoros fejlődés között mutatkozott jelentős összefüggés miatt tervezzük az adatgyüjtést a kutatásban együttmúködési szándékukat visszajelző, a bántalmazott nőknek és gyermekeiknek otthont adó rejtett házakban is. Továbbá távlati terveink között szerepel egy, kétéves korban történő országos pszichodiagnosztikai szűrővizsgálat kötelező bevezetésének elősegítése, illetve a koraszülött gyermekek longitudinális vizsgálatának kivitelezése.

Anyagi támogatás: A kutatás az Emberi Erőforrások Minisztériuma ÚNKP-16-21 kódszámú Új Nemzeti Kiválóság Programjának támogatásával készültt.

Szerzôi munkamegosztás: Sz. A. Sz.: Szakirodalom gyüjtése és feldolgozása, vizsgálat megtervezése, adatfelvétel megszervezése, vizsgálati időpontok egyeztetése, vizsgálatok kivitelezése, adatbevitel, kiértékelés, statisztikai eredmények értelmezése, adatok leíró elemzése, kézirat megszövegezése. N. B. E.: A vizsgálati téma felvetése, a vizsgálat megtervezése, a vizsgálat céljainak meghatározása, szupervíziója, az adatfelvétel megszervezése, statisztikai eredmények értelmezése, a kézirat megszövegezése. A cikk végleges változatát mindkét szerző elolvasta és jóváhagyta.

Érdekeltségek: A szerzőknek nincsenek érdekeltségeik.

\section{Köszönetnyilvánítás}

Ezúton szeretnénk kifejezni köszönetünket Prof. Dr. Balla Györgynek, a Debreceni Egyetem, Klinikai Központ, Gyermekgyógyászati Intézet igazgatójának, hogy lehetővé tette vizsgálataink kivitelezését.

\section{Irodalom}

[1] Danis I, Farkas M, Oates J. Development in the early childhood. How shall we think about it? In: Danis I, Farkas M, Herczog M, et al. (eds.) Nature of early childhood's development - developmental steps and challenges. [Fejlödés a koragyermekkorban: Hogyan is gondolkod(j)unk róla? In: Danis I, Farkas M, Herczog M, et al. (szerk.) A koragyermekkori fejlődés természete fejlődési lépések és kihívások.] Nemzeti Család- és Szociálpolitikai Intézet, Budapest, 2011; pp. 24-66. [Hungarian]

[2] Danis I, Kalmár M. The nature and models of development. In: Danis I, Farkas M., Herczog M, et al. (eds.) The genes to society: the early childhood development areas. [A fejlödés természete és modelljei. In: Danis I, Farkas M, Herczog M, et al. (szerk.) A génektől a társadalomig: a koragyermekkori fejlődés színterei.] Nemzeti Család- és Szociálpolitikai Intézet, Budapest, 2011; pp. 76-124. [Hungarian]

[3] Gallai M, Vetier A. Move, perceive, be active and healthy! - Physical growth, motor and sensory development as well as health. In: Danis I, Farkas M, Herczog M, et al. (eds.) Nature of early childhood's development - developmental steps and challenges. [Mozogj, érzékelj, légy aktív és egészséges! - Testi növekedés, motoros és érzékszervi fejlődés, valamint az egészség. In: Danis I, Farkas M, Herczog M, et al. (szerk.) A koragyermekkori fejlődés természete - fejlődési lépések és kihívások.] Nemzeti Család- és Szociálpolitikai Intézet, Budapest, 2011; pp. 102144. [Hungarian]

[4] Liu L, Johnson HL, Cousens S, et al. Global, regional, and national causes of child mortality: an updated systematic analysis for 
2010 with time trends since 2000 . Lancet $2012 ; 379: 2151-$ 2161

[5] UNICEF. Children well-being in the world's rich countries. [Gyermekek jólléte a világ fejlett országaiban.] Az UNICEF Innocenti Kutatóintézetének 2013. évi jelentése, 2013. [Hungarian]

[6] Asszmann A. Women, mother, infant and children protection. In: Ádány R. (ed.) Preventive medicine and public health. [A nő-, anya-, csecsemő- és gyermek-egészségvédelem. In: Ádány R. (szerk.) Megelőző orvostan és népegészségtan.] Medicina Könyvkiadó, Budapest, 2012; pp. 520-538. [Hungarian]

[7] Kalmár M. The brain development threatening factors and possibilities of averting threats. In: Danis I, Farkas M, Herczog M, et al. (eds.) The genes to society: the early childhood development areas. [Az agy fejlódését veszélyeztetó tényezők és a veszélyek elhárításának lehetőségei. In: Danis I, Farkas M, Herczog M, et al. (szerk.) A génektől a társadalomig: a koragyermekkori fejlődés színterei.] Nemzeti Család- és Szociálpolitikai Intézet, Budapest, 2011; pp. 206-229. [Hungarian]

[8] Görbe É. Premature baby in the family. [Koraszülött a családban.] White Golden Book Kft., Budapest, 2004. [Hungarian]

[9] Balázs P, Fogarasi-Grenczer A, Rákóczi I, et al. Epidemiology of preterm birth in the north east of Hungary. [A koraszülés epidemiológiája Északkelet-Magyarországon.] Gyermekgyógyászat 2015; 66: 114-120. [Hungarian]

[10] Wosu AC, Gelaye B, Williams MA. Maternal history of childhood sexual abuse and preterm birth: an epidemiologic review. BMC Pregnancy Childbirth 2015; 15: 174.

[11] Selk SC, Rich-Edwards JW, Koenen K, et al. An observational study of type, timing, and severity of maltreatment and preterm birth. J Epidemiol Community Health 2016; 70: 589-595.

[12] Leeners B, Stiller R, Block E, et al. Pregnancy complications in women with childhood sexual abuse experience. J Psychosom Res. 2010; 69: 503-510

[13] Hill A, Pallitto C, McCleary-Sills J, et al. A systematic review and meta-analysis of intimate partner violence during pregnancy and selected birth outcomes. Int J Gynecol Obstet. 2016; 133: 269276.

[14] Kuritárné Szabó I. Child maltreatment and its consequences. In: Kuritárné Szabó I, Tisljár-Szabó E. (eds.) I would have liked not to be maltreated. Child maltreatment: theory and therapy. [A gyermekkori családon belüli traumatizáció és következményei. In: Kuritárné Szabó I, Tisljár-Szabó E. (szerk.) Úgy szerettem volna, ha nem bántottak volna. A családon belüli gyermekkori traumatizáció: elmélet és terápia.] Oriold és Társai Kiadó, Budapest, 2015; pp. 13-52. [Hungarian]

[15] Butchart A, Harvey AP, Mian M, et al. Preventing child maltreatment: a guide to taking action and generating evidence. World Health Organization and International Society for Prevention Child Abuse and Neglect, Geneva, 2006.

[16] NANE Society. WHY does she stay? Domestic and intimate partner violence. How could we help? Manual for experts who work at helper profession. [NANE Egyesület. MIÉRT marad? Családon belüli és párkapcsolati erőszak. Hogyan segíthetünk? Kézikönyv segítő foglalkozású szakemberek számára.] NANE Egyesület, Budapest, 2015. [Hungarian]

[17] Wirth J. Public policy recommendations of Hungarian Women's Lobby in connection with violence against women. In: Juhász B. (ed.) Public policy recommendations of Hungarian Women's Lobby. [A Magyar Női Érdekérvényesítő Szövetség közpolitikai ajánlásai a nők elleni erőszak területén. In: Juhász B. (szerk.) A Magyar Női Érdekérvényesítő Szövetség közpolitikai ajánlásai.] Bölcsész Konzorcium, Budapest, 2016; pp. 99-111. [Hungarian]

[18] Kalmár M, Boronkai J. The role of quality of home environment in preterm children long-term intellectual development. [Az otthoni környezet minőségének szerepe koraszülött gyerekek hosszú távú értelmi fejlődésében.] Magyar Pszichológiai Szemle 2001; 56: 387-410. [Hungarian]

[19] Váradi V, Görbe É. The healthy and the sick newborn (neonatology). In: Papp Z. (ed.) The textbook of obstetrics-gynaecoloy. [Az egészséges és a beteg újszülött (neonatológia). In: Papp Z. (szerk.) A szülészet-nőgyógyászat tankönyve.] Semmelweis Kiadó, Budapest, 2009; pp. 377-408. [Hungarian]

[20] Heffner-Sarkar S, Kulcsár J. PIC brochure, important help. Premature baby Association. [PICi füzet nagy segítség. Koraszülöttekért Közhasznú Egyesület.] Budapest, 2015. [Hungarian]

[21] Bhutta AT, Cleves MA, Casey PH, et al. Cognitive and behavioral outcomes of school-aged children who were born preterm: a meta-analysis. JAMA $2002 ; 288,728-737$.

[22] van Noort-van der Spek IL, Franken JP, Weisglas-Kuperus N. Language functions in preterm children: A systematic review and meta-aAnalysis. Pediatrics 2012; 129: 745-754.

[23] Aarnoudse-Moens CS, Weisglas-Kuperus N, van Goudoever JB, et al. Meta-analysis of neurobehavioral outcomes in very preterm and/or very low birth weight children. Pediatrics 2009; 124: 717-730.

[24] Månsson J, Stjernqvist K. Children born extremely preterm show significant lower cognitive, language and motor function levels compared with children born at term, as measured by the BayleyIII at 2.5 years. Acta Pediatr. 2014; 103: 504-511.

[25] Sansavini A, Pentimonti J, Justice L, et al. Language, motor and cognitive development of extremely preterm children: Modeling individual growth trajectories over the first three years of life. J Commun Disord. 2014; 49: 55-68.

[26] Ionio C, Riboni E, Confalonieri E, et al. Paths of cognitive and language development in healthy preterm infants. Infant Behav Dev. 2016; 44: 199-207.

[27] Benassi E, Savini S, Iverson JM, et al. Early communicative be haviors and their relationship to motor skills in extremely preterm infants. Res Dev Disabil. 2016; 48: 132-144.

[28] Sansavini A, Guarini A, Savini S. Linguistic and cognitive delays in very preterm infants at 2 years: general or specific delays? Revista de Logopedia Foniatría y Audiología 2011; 31: 133-147.

[29] Constantinou JC, Adamson-Macedo EN, Mirmiran M, et al. Neurobehavioral assessment predicts differential outcome between VLBW and ELBW preterm infants. J Perinatol. 2005; 25 : 788-793.

[30] Martins C, Gaffan EA. Effects of early maternal depression on patterns of infant-mother attachment: a meta-analytic investigation. J Child Psychol Psychiatr. 2000; 41: 737-746.

[31] Nagy BE. Psychoterapy and rehabilitation in child benefit in the light of special needs children studies. [Pszichoterápia és rehabilitáció a gyermekellátásban a speciális szükségletü gyermekekkel végzett vizsgálatok tükrében.] Didakt Kiadó, Debrecen, 2007. [Hungarian]

[32] Farkas M, Csiky E. The Brunet-Lézine scale use for early detection of childhood psychomotor development disorders. [A Brunet-Lézine-féle vizsgálati módszer alkalmazása a gyermekkori pszichomotoros fejlődés zavarainak korai felismerésében.] Múvelődési Minisztérium, Budapest, 1980. [Hungarian]

[33] Bayley N. Bayley scales of infant and toddler development - third edition. The Psychological Corporation, San Antonio, TX, 2006.

[34] Kenyhercz F, Nagy BE. Examination of psychomotor development in relation to social-environmental factors in preterm children at 2 years old. [Koraszülött gyermekek kétéves kori pszichomotoros fejlődése társas-környezeti tényezők függvényében.] Orv Hetil. 2017; 158: 31-38. [Hungarian]

[35] Atkinson L, Paglia A, Coolbear J, et al. Attachment security: a meta-analysis of maternal mental health correlates. Clin Psychol Rev. 2000; 20: 1019-1040.

(Szele Anna Szabina, Tiszaigar, Rákóczi út 24/A, 5361 e-mail: szeleanna93@gmail.com) 